\title{
The impact of biofilm formation on implantable cardiac devices
}

\author{
O impacto da formação de biofillmes em dispositivos cardíacos implantáveis \\ El impacto de la formación de biopelículas en los dispositivos cardíacos implantables
}

Received: 11/17/2021 | Reviewed: 11/25/2021 | Accept: 11/27/2021| Published: 12/09/2021

\author{
Nicole Abdullah \\ ORCID: https://orcid.org/0000-0001-7728-0862 \\ Faculdades Pequeno Príncipe, Brazil \\ E-mail: nicabdullah4@ gmail.com \\ Oona Salomão Erdmann \\ ORCID: https://orcid.org/0000-0001-8100-7658 \\ Faculdades Pequeno Príncipe, Brazil \\ E-mail: oonaserdmann@gmail.com \\ Beatriz Essenfelder Borges \\ ORCID: https://orcid.org/0000-0001-9750-5635 \\ Faculdades Pequeno Príncipe, Brazil \\ E-mail: biaessenfelder@gmail.com
}

\begin{abstract}
Introduction: biofilm is a culture of sessile bacteria, isolated from the external world, capable of internal communication and signalization, which allow for the development of phenotypic changes to adapt to hostile environments. Given its easy pathogenic dissemination, biofilms can develop in prosthetics and implantable medical devices, forming focal nosocomial infections. Objective: to comprehend biofilm formation mechanisms in implantable cardiac devices in an intra-hospital environment, as well as the treatment and prophylactic measures to treat this condition. Materials and methods: descriptive and observational exploratory study based on a literary review on biofilm formation, its consequences in a hospital environment, and infections caused by proliferation on implantable cardiac devices. In total, 28 articles were selected using the following descriptors: ((nosocomial) AND (cardiac)) AND (devices). Results: biofilm grows in an uneven form, being influenced by strain and environment. It has a high virulence when it comes to growing on implantable cardiac devices considering its ability to adhere to biotic and abiotic surfaces. Immunosuppression and the lack of surgical sterilization are factors that can contribute to complications associated with the use of these devices, such as infectious endocarditis. Conclusion: biofilm, due to its pathogenicity and virulence, is a serious though rare complication in patients that use implantable devices. There is evidence that contamination occurs mainly in surgical environments, making it necessary the application of more rigorous sterilization techniques.
\end{abstract}

Keywords: Biofilms; Cardiac Resynchronization Therapy Devices; Cross infection.

\section{Resumo}

Introdução: O biofilme é uma comunidade de bactérias sésseis, isolada do meio externo, que possui capacidade de comunicação interna e sinalizações que promovem mudanças fenotípicas a fim de se adaptar a condições hostis. Pela fácil disseminação patogênica, os biofilmes podem se desenvolver em próteses e aparelhos médicos implantáveis e culminar em sítios de infecção nosocomial. Objetivo: Compreender os mecanismos de desenvolvimento dos biofilmes bacterianos em dispositivos cardíacos implantáveis no ambiente intra-hospitalar, bem como os possíveis manejos de tratamento e profilaxia. Materiais e Métodos: realizou-se um estudo observacional descritivo e exploratório por meio de uma revisão de literatura acerca da formação de biofilmes, suas consequências no meio hospitalar, e posterior infecção no organismo por meio dos dispositivos cardíacos implantáveis, resultando na seleção de 28 artigos com base nos descritores ((nosocomial) AND (cardiac)) AND (devices). Resultados: O biofilme possui um crescimento heterogêneo, dependente da cepa e o ambiente para a proliferação. Podendo se aderir em superfícies bióticas e abióticas, possui uma alta virulência em afetar os dispositivos cardíacos implantáveis. A falta de esterilização cirúrgica e imunossupressão são fatores que podem culminar em complicações ao uso desses dispositivos, tal como a endocardite infecciosa. Conclusão: $\mathrm{O}$ biofilme, devido à patogenicidade e virulência, é uma complicação que, apesar de rara, é grave em pacientes com utilização de aparelhos implantáveis. Há evidências de que a contaminação ocorre principalmente nos meios cirúrgicos, sendo necessário medidas mais rígidas de esterilização.

Palavras-chave: Biofilmes; Dispositivos de Terapia de Ressincronização Cardíaca; Infecção hospitalar.

\section{Resumen}

Introducción: Biopelícula es una comunidad de bacterias sésiles, aisladas del medio externo, que tiene la capacidad de comunicación interna y señales que promueven cambios fenotípicos para adaptarse a condiciones hostiles. Debido a la 
fácil diseminación patógena, las biopelículas pueden desarrollarse en prótesis implantables y dispositivos médicos y culminar en sitios de infección nosocomial. Objetivo: Comprender los mecanismos de desarrollo de biopelículas bacterianas en dispositivos cardíacos implantables en el ámbito hospitalario, así como las posibles gestiones de tratamiento y profilaxis. Materiales y Métodos: Se hizo un estudio observacional descriptivo y exploratorio mediante una revisión de la literaturas sobre la formación de biopelículas, sus consecuencias en el medio hospitalario y la posterior infección en el cuerpo a través de dispositivos cardíacos implantables, resultando en la selección de 28 artículos basados en los descriptores ((nosocomial) AND (cardíaco)) AND (dispositivos). Resultados: La biopelícula tiene un crecimiento heterogéneo, dependiendo de la cepa y el entorno de proliferación. Al poder adherirse a superficies bióticas y abióticas, tiene una alta virulencia al afectar a los dispositivos cardíacos implantables. La falta de esterilización quirúrgica e inmunosupresión son factores que pueden derivar en complicaciones en el uso de estos dispositivos, como la endocarditis infecciosa. Conclusión: la biopelícula, por su patogenicidad y virulencia, es una complicación que, aunque sea rara, es grave en pacientes que utilizan dispositivos implantables. Existe evidencia de que la contaminación ocurre principalmente en ambientes quirúrgicos, requiriendo medidas de esterilización más estrictas.

Palabras clave: Biopelículas; Dispositivos de Terapia de Resincronización Cardíaca; Infección hospitalaria.

\section{Introduction}

Biofilm can be defined as a community of conjugated microorganisms, with reduced metabolism, which adhere to biotic or abiotic surfaces and secrete an extracellular matrix that surrounds them (Henriques et al., 2013). This layer is made up of extracellular polymeric substances (EPS), like polysaccharides, carbohydrates, proteins, and nucleic acids; it has a liquid aspect, giving the culture a higher antimicrobial resistance, protecting them against mechanical forces (Henriques et al., 2013; Sousa et al., 2017).

Its medical importance exists due to its increased resistance against antimicrobial substances when compared to its innature homologous - planktonic bacterial cells - and, consequently, diseases in which biofilms are present and active tend to be chronic and of difficult eradication (Marks et al., 2014). It acts as a continuous contamination and infection source when compared to planktonic bacteria (Henriques et al., 2013). The following factors contribute to the difficulty in controlling and eliminating this type of culture: morphological aggregation properties, immune system evasion mechanisms, and resistancegene transfer between members of the microbiota (Henriques et al., 2013; Sousa et al., 2017). A planktonic bacteria can be released from a mature biofilm and colonize other surfaces. If adhesion does occur, it will form, once again, a new biofilm, implicating in quick propagation that is more complicated to exterminate (Hall et al., 2017). The infection characteristics of each biofilm depend on the type of bacteria composing it. For example, those formed by Staphylococcus aureus and Staphylococcus epidermidis may colonize cardiac pacemakers, provoking serious cardiac diseases, and discarding the device (Hall et al., 2017). The biofilms, to have a strong adherence to the pacemaker, activate genes and intensify the pathogenicity mechanisms (Santos et al., 2011).

The biofilm's pathogenicity begins when the infection happens, and afterward, adheres to other surfaces. Planktonic bacteria - the free-life counterparts - are metabolically active and essential in rapid microorganism dissemination. The interaction of planktonic bacteria with a surface is the first step in biofilm formation (Araújo et al., 2010; Moraes et al., 2013; Nascimento et al., 2018). After the establishment of the community, begins the process of detachment of peripheric cells, dispersion, and new adhesion processes (Araújo et al., 2010).

A means of bacterial contamination is the hospital environment, through medical and non-medical materials, favoring the development of biofilm, in addition to the promiscuous cleaning of hospital beds (Sued et al., 2017). Bacterial infection caused by pathogens such as $S$. epidermidis and $S$. aureus can originate in such environments, infecting prosthesis, pacemakers, and orthopedic cardiac valves. (Dengler Haunreiter et al., 2019; Hall et al., 2017). Septic problems at the implantation site can provoke a bacterial infection that, as a resistant strain, is even more tolerant to antimicrobials - the longer it takes to treat the patient. (Dengler Haunreiter et al., 2019) 
The pacemaker is a permanent implantable cardiac device and was revolutionary in the treatment of cardiac arrhythmias and, in today's medical field, is the most promising treatment evolution for this clinical condition (Santos et al., 2011). Although new technologies make implant-related procedures easier, the number of infections - and their consequences - associated with cardiac devices has increased proportionally to the need to use them (Sousa et al., 2017).

The goal of this review is to understand the biofilm, the impact of its proliferation in implantable cardiac devices, its pathogenicity and consequences in the patients' health. It also seeks to elucidate the factors that can promote and prevent the interaction between bacteria and specific surfaces, allowing it to be studied.

\section{Methodology}

It is a descriptive and observational exploratory study based on a literary review on biofilm formation, its consequences in a hospital environment, and infections caused by implantable cardiac devices. The main systematic conjecture sought with this premise was Infectious Endocarditis, subject to quantitative analysis. The articles were selected in PubMed and VHL databases with the following descriptors: ((nosocomial) AND (cardiac)) AND (devices). The coverage period included in this study was 2014 to 2021 , using the proper descriptors. Some sporadic articles, before 2016, were selected with our adviser for the improvement of our project. All of them are in the aforementioned databases with the respective descriptors. These word methods were selected via DeCS (descriptors in health sciences), and non-controlled descriptors were not used.

In allusion to the inclusion methods, a research question was formed: What is the impact and consequences of the biofilm formation in implantable cardiac devices. The selected articles responded to the proposed inquiry. Duplicated articles, non-articles, and papers that did not answer the research question were excluded, as well as those with obsolete information. This review was written during the years 2020 and 2021.

After the application of the descriptors, the search resulted in 381 articles, 234 in PubMed and 147 in VHL. After duplicate exclusion, the value decreased to 238 . Of those, 184 were excluded due to unavailability or title and abstract that did not answer the research question, leading to 54 articles, which were read in its integrity. 26 were excluded after this step, and the 28 remaining are referenced in the discussion of this paper (Figure 1).

\section{Results}

This review was based on randomized controlled trials, non-randomized controlled trials, prospective and retrospective cohorts, case-control, transversal analytical, case series, individual case report, and descriptive cross-sectional studies and editorial.

The search resulted in a total of 28 studies after the exclusion of duplicated articles, studies that did not encompass the objective, and that were not available for the review. An illustration of the research process that follows the PRISMA methodology (Preferred Reporting Items for Systematic Reviews and Meta-Analyses) can be found in Figure 1. 
Figure 1: PRISMA Method for article inclusion.

Research problem: the impact of biofilm development in implantable cardiac devices.
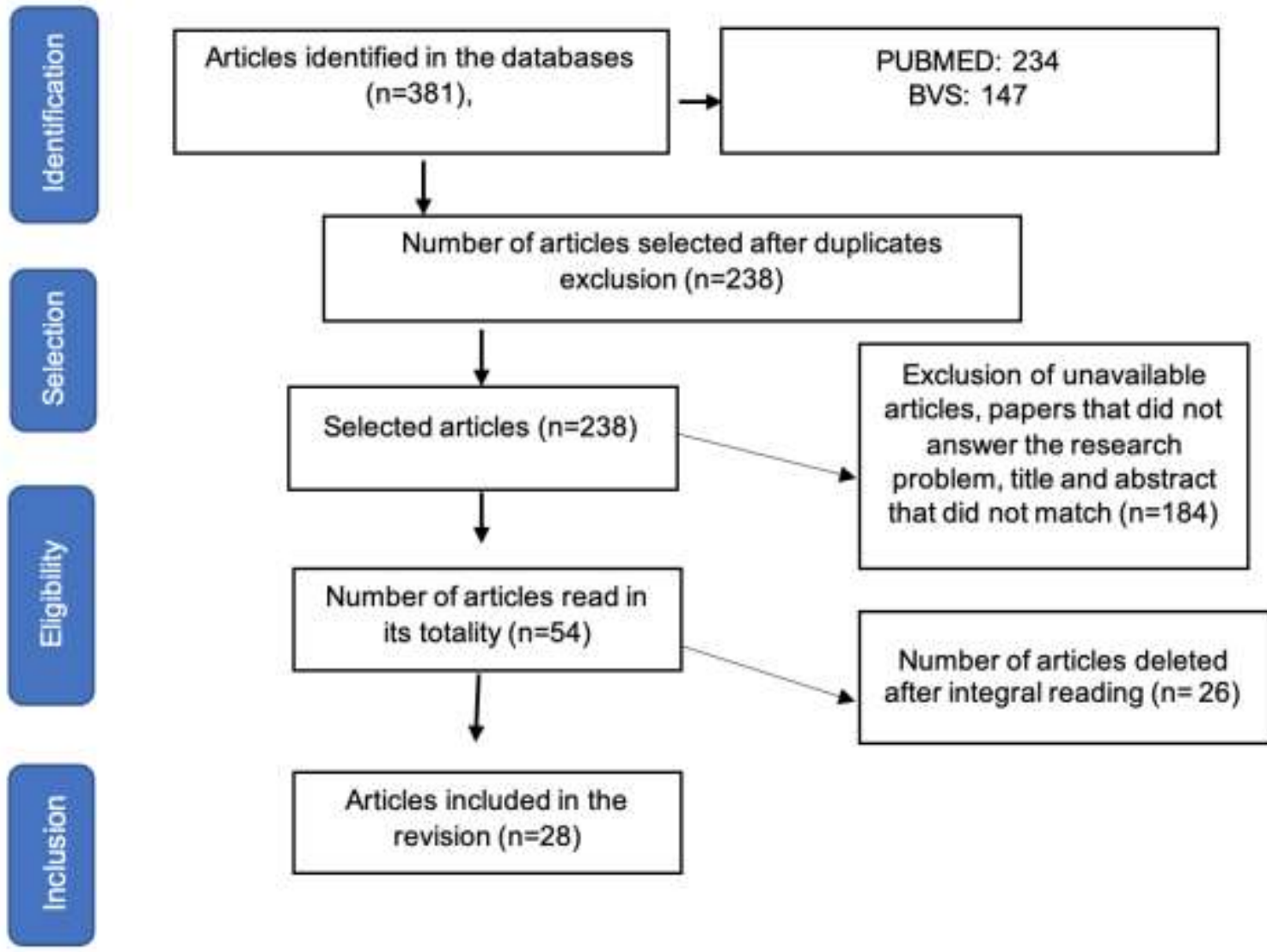

Articles included in the

revision $(n=28)$

Source: Authors (2021).

Table 1: Articles Categorization.

\begin{tabular}{|c|c|c|c|c|c|}
\hline Authors & Year & Title & Journal & Method & $\begin{array}{c}\text { Results } \\
\end{array}$ \\
\hline $\begin{array}{l}\text { Al-Shamiri M, } \\
\text { Zhang S, Mi P, } \\
\quad \text { et al. }\end{array}$ & 2021 & $\begin{array}{lr}\text { Phenotypic and } & \text { genotypic } \\
\text { characteristics of Acinetobacter } \\
\text { baumannii enrolled in the } \\
\text { relationship } & \text { among } \\
\text { antibiotic resistance, } \\
\text { formation and motility }\end{array}$ & $\begin{array}{c}\text { Microbial } \\
\text { Pathogenesis }\end{array}$ & $\begin{array}{l}\text { Experimental } \\
\text { study }\end{array}$ & $\begin{array}{l}\text { Resistant A. baumannii strains } \\
\text { were more capable of forming } \\
\text { biofilms than sensitive strains }\end{array}$ \\
\hline $\begin{array}{c}\text { Araújo E, } \\
\text { Andrade N, } \\
\text { Carvalho A, et } \\
\text { al. }\end{array}$ & 2010 & $\begin{array}{l}\text { Aspectos coloidais da adesão de } \\
\text { microorganismos }\end{array}$ & Química Nova & $\begin{array}{l}\text { Integrative } \\
\text { review }\end{array}$ & $\begin{array}{l}\text { Biofilm's stability relies on Van } \\
\text { der Waals, electrostatic forces, and } \\
\text { Lewis' acid-base properties; } \\
\text { Hydrophobia, electric charge and } \\
\text { environmental condition also } \\
\text { influence the adhesion process }\end{array}$ \\
\hline $\begin{array}{l}\text { Berkefeld A, } \\
\text { Berger F, } \\
\text { Gärtner B, et al. }\end{array}$ & 2020 & $\begin{array}{l}\text { Clostridioides } \quad \text { (Clostridium) } \\
\text { difficile Pacemaker Infection }\end{array}$ & $\begin{array}{l}\text { Open Forum } \\
\text { Infectious } \\
\text { Diseases }\end{array}$ & Case report & $\begin{array}{l}\text { C. difficile bacteremia is usually } \\
\text { associated with GI pathologies, } \\
\text { immunosuppression and severe } \\
\text { comorbidities, but has had } \\
\text { increased incidence associated } \\
\text { with implantable devices }\end{array}$ \\
\hline $\begin{array}{l}\text { Brackman } \mathrm{G}, \\
\text { Coenye } \mathrm{T}\end{array}$ & 2014 & $\begin{array}{l}\text { Quorum Sensing Inhibitors as } \\
\text { Anti-Biofilm Agents }\end{array}$ & $\begin{array}{l}\text { Current } \\
\text { Pharmaceutical } \\
\text { Design }\end{array}$ & Review & $\begin{array}{l}\text { The role of QS in biofilm } \\
\text { establishment does not have a } \\
\text { consensus yet, however, QSI may } \\
\text { be promising in treating this } \\
\text { condition }\end{array}$ \\
\hline $\begin{array}{l}\text { Bruna C, } \\
\text { Almeida A, } \\
\text { Graziano K }\end{array}$ & 2019 & $\begin{array}{l}\text { Avaliação da } \quad \text { contaminação } \\
\text { microbiana em fitas e resinas } \\
\text { identificadoras de instrumental } \\
\text { cirúrgico }\end{array}$ & Revista SOBECC & $\begin{array}{l}\text { Experimental } \\
\text { laboratorial } \\
\text { study }\end{array}$ & $\begin{array}{l}\text { The impact of resins on surgery } \\
\text { materials in bacterial infections } \\
\text { during a procedure and how it } \\
\text { contributes to biofilm }\end{array}$ \\
\hline
\end{tabular}




\begin{tabular}{|c|c|c|c|c|c|}
\hline $\begin{array}{l}\text { Degler HV, } \\
\text { Boumasmoud } \\
\text { M, Häffner N, } \\
\text { et al. }\end{array}$ & 2019 & $\begin{array}{l}\text { In-host evolution of } \\
\text { Staphylococcus epidermidis in a } \\
\text { pacemaker-associated endocarditis } \\
\text { resulting in increased } \\
\text { antibiotic tolerance }\end{array}$ & $\begin{array}{c}\text { Nature } \\
\text { Communications }\end{array}$ & Experimental & $\begin{array}{l}\text { Antimicrobial tolerance has a role } \\
\text { in biofilm formation of chronic } \\
\text { and difficult to treat bacterial } \\
\text { infections }\end{array}$ \\
\hline $\begin{array}{l}\text { DeSimone D, } \\
\text { DeSimone C, et } \\
\text { al. }\end{array}$ & 2020 & $\begin{array}{l}\text { Editorial commentary: } \\
\text { Intravenous drug abuse } \\
\text { and infectious endocarditis }\end{array}$ & $\begin{array}{l}\text { Trends in } \\
\text { Cardiovascular } \\
\text { Medicine }\end{array}$ & $\begin{array}{c}\text { Editorial } \\
\text { Commentary }\end{array}$ & $\begin{array}{l}\text { Abusive intravenous drug use to } \\
\text { treat infectious endocarditis has } \\
\text { major public health repercussions }\end{array}$ \\
\hline Devine A & 2014 & $\begin{array}{l}\text { Hardware for the Heart: The } \\
\text { Increasing Impact of Pacemakers } \\
\text { ICDs, and LVADs }\end{array}$ & $\begin{array}{l}\text { MD Edge } \\
\text { Emergency } \\
\text { Medicine }\end{array}$ & Review & $\begin{array}{l}\text { Pacemakers complications can be } \\
\text { diagnosed via medical history and } \\
\text { examination, and are manageable }\end{array}$ \\
\hline Hall C, Mah T & 2017 & $\begin{array}{l}\text { Molecular mechanisms of biofilm- } \\
\text { based antibiotic resistance and } \\
\text { tolerance in pathogenic bacteria }\end{array}$ & $\begin{array}{c}\text { FEMS } \\
\text { Microbiology } \\
\text { Reviews }\end{array}$ & Review & $\begin{array}{l}\text { Biofilm has a variety of virulence } \\
\text { mechanisms, allowing it to be } \\
\text { antimicrobial-tolerant }\end{array}$ \\
\hline $\begin{array}{l}\text { Hannachi N, } \\
\text { Habib G, } \\
\text { Camoin-Jau L }\end{array}$ & 2019 & $\begin{array}{l}\text { Aspirin Effect of Staphylococcus } \\
\text { aureus - Platelet Interactions } \\
\text { During Infectious Endocarditis }\end{array}$ & Frontiers Medicine & Experimental & $\begin{array}{l}\text { The use of aspirin as a } \\
\text { prophylactic measure against } \\
\text { infectious endocarditis has not } \\
\text { been well established }\end{array}$ \\
\hline $\begin{array}{l}\text { Henriques A, } \\
\text { Vasconcelos C, } \\
\text { Cerca N }\end{array}$ & 2013 & $\begin{array}{l}\text { A importância dos biofilmes nas } \\
\text { infeções nosocomial: o estado da } \\
\text { arte }\end{array}$ & $\begin{array}{l}\text { Arquivos de } \\
\text { Medicina }\end{array}$ & Review & $\begin{array}{l}\text { The knowledge of biofilms in an } \\
\text { intra-hospital environment allows } \\
\text { for studies focused on reducing its } \\
\text { incidence and mortality }\end{array}$ \\
\hline $\begin{array}{l}\text { Hentzer M, } \\
\text { Givskov M }\end{array}$ & 2003 & $\begin{array}{l}\text { Pharmacological inhibition of } \\
\text { quorum sensing for the treatment } \\
\text { of chronic bacterial infections }\end{array}$ & $\begin{array}{l}\text { Journal of Clinical } \\
\text { Investigation }\end{array}$ & Review & $\begin{array}{l}\text { Quorum-Sensing Inhibitors are } \\
\text { new form of treating and } \\
\text { preventing biofilm by acting } \\
\text { directly on bacteria-to-bacterial } \\
\text { communication, preventing its } \\
\text { dissemination }\end{array}$ \\
\hline $\begin{array}{l}\text { Holland T, } \\
\text { Baddour L, } \\
\text { Bayer A, et al. }\end{array}$ & 2016 & Infective endocarditis & $\begin{array}{l}\text { Nature Reviews } \\
\text { Disease Primers }\end{array}$ & $\begin{array}{l}\text { Integrative } \\
\text { Review }\end{array}$ & $\begin{array}{l}\text { The prophylaxis remains the only } \\
\text { effective solution, but some } \\
\text { antimicrobial agents have } \\
\text { demonstrated a percentage of } \\
\text { successful eradication of biofilms } \\
\text { in EI patientes. }\end{array}$ \\
\hline $\begin{array}{l}\text { Ma Y, Chen M, } \\
\text { Jones J, et al. }\end{array}$ & 2012 & $\begin{array}{lr}\text { Inhibition of } & \text { Staphylococcus } \\
\text { epidermidis } & \text { Biofilm by } \\
\text { Trimethylsilane Plasma Coating }\end{array}$ & $\begin{array}{l}\text { Antimicrobial } \\
\text { Agents and } \\
\text { Chemotherapy }\end{array}$ & Experimental & $\begin{array}{l}\text { Development of a novel plasma } \\
\text { coating with trimethylsilane. The } \\
\text { coat successfully demonstrated a } \\
\text { decrease of biofilm formation in } \\
\text { Stainless Steel surfaces, one of the } \\
\text { most common substances in } \\
\text { hospitalar devices. }\end{array}$ \\
\hline $\begin{array}{l}\text { Marks L, } \\
\text { Reddinger R, } \\
\text { Hakasson A }\end{array}$ & 2014 & $\begin{array}{l}\text { Biofilm Formation Enhances } \\
\text { Fomite Survival of Streptococcus } \\
\text { pneumoniae and Streptococcus } \\
\text { pyogenes }\end{array}$ & $\begin{array}{l}\text { Infection and } \\
\text { Immunity }\end{array}$ & Experimental & $\begin{array}{l}\text { Demonstrate high chances of } \\
\text { bacterial dissemination through } \\
\text { surfaces, which can be also an } \\
\text { ambient of bacterial colonization }\end{array}$ \\
\hline $\begin{array}{l}\text { Moraes M, } \\
\text { Silveira W, } \\
\text { Teixeira L, et } \\
\text { al. }\end{array}$ & 2013 & $\begin{array}{l}\text { Mechanisms of bacterial adhesion } \\
\text { to biomaterials }\end{array}$ & $\begin{array}{l}\text { Revista Médica de } \\
\text { Minas Gerais }\end{array}$ & $\begin{array}{l}\text { Observational } \\
\text { study }\end{array}$ & $\begin{array}{l}\text { Mechanisms of biofilm formation } \\
\text { in biosurfaces and its current } \\
\text { prophylaxis }\end{array}$ \\
\hline $\begin{array}{l}\text { Nascimento IR, } \\
\text { Lema de Sena } \\
\text { T, Fernandes } \\
\text { dos Santos } \\
\text { Castro F, et al. }\end{array}$ & 2018 & $\begin{array}{l}\text { Biofilmes bacterianos: } \\
\text { colonização e identificação de } \\
\text { micro-organismos causadores de } \\
\text { infecção em cateter venoso central }\end{array}$ & $\begin{array}{l}\text { Programa de } \\
\text { Iniciação } \\
\text { Científica - } \\
\text { PIC/UniCEUB - } \\
\text { Relatórios de } \\
\text { Pesquisa }\end{array}$ & $\begin{array}{l}\text { Observational } \\
\text { study }\end{array}$ & $\begin{array}{l}\text { The development of biofilm } \\
\text { formation in venous central } \\
\text { catheter }\end{array}$ \\
\hline $\begin{array}{l}\text { Nguemeleu ET, } \\
\text { Boivin S, } \\
\text { Robins S, et al. }\end{array}$ & 2020 & $\begin{array}{l}\text { Development and validation of a } \\
\text { time and motion guide to assess } \\
\text { the costs of prevention and control } \\
\text { interventions for nosocomial } \\
\text { infections: A Delphi method } \\
\text { among experts }\end{array}$ & PLOS ONE & $\begin{array}{l}\text { Delphi } \\
\text { Review }\end{array}$ & $\begin{array}{l}\text { Assessment costs of nosocomial } \\
\text { infection in healthcare system }\end{array}$ \\
\hline $\begin{array}{l}\text { Rabin N, Zheng } \\
\text { Y, Opoku- } \\
\text { Temeng C, et } \\
\text { al. }\end{array}$ & 2015 & $\begin{array}{l}\text { Biofilm formation mechanisms } \\
\text { and targets for developing } \\
\text { antibiofilm agents }\end{array}$ & $\begin{array}{l}\text { Future Medicinal } \\
\text { Chemistry }\end{array}$ & $\begin{array}{l}\text { Integrative } \\
\text { Review }\end{array}$ & $\begin{array}{l}\text { In marge of the biofilm virulence } \\
\text { and pathogenesis, it's necessary to } \\
\text { overcome the barriers in these } \\
\text { communities to successfully } \\
\text { eradicate its consolidation }\end{array}$ \\
\hline
\end{tabular}




\begin{tabular}{|c|c|c|c|c|c|}
\hline $\begin{array}{l}\text { Salmeri M, } \\
\text { Sorbello M, } \\
\text { Mastrojeni S, et } \\
\text { al. }\end{array}$ & 2016 & $\begin{array}{l}\text { Infections of cardiovascular } \\
\text { implantable electronic devices in } \\
\text { an Italian hospital }\end{array}$ & $\begin{array}{l}\text { Le Infezioni in } \\
\text { Medicina }\end{array}$ & $\begin{array}{l}\text { Longitudinal } \\
\text { Study }\end{array}$ & $\begin{array}{l}\text { An analysis of the occurrence of } \\
\text { infections of cardiovascular } \\
\text { devices in patients on use of } \\
\text { pacemakers. }\end{array}$ \\
\hline $\begin{array}{l}\text { Santos A, } \\
\text { Watanabe E, } \\
\text { Andrade D }\end{array}$ & 2011 & $\begin{array}{l}\text { Biofilme em marca-passo } \\
\text { artificial: ficção ou realidade? }\end{array}$ & $\begin{array}{l}\text { Arquivos } \\
\text { Brasileiros de } \\
\text { Cardiologia }\end{array}$ & $\begin{array}{l}\text { Integrative } \\
\text { Review }\end{array}$ & $\begin{array}{l}\text { Expose the main risk factors of } \\
\text { biofilm adhesion and its } \\
\text { consequences for a cardiopathic } \\
\text { patient in use of pacemakers }\end{array}$ \\
\hline $\begin{array}{l}\text { Sousa Á MD, } \\
\text { Monteiro R, et } \\
\text { al. }\end{array}$ & 2017 & $\begin{array}{l}\text { Prevenção da formação de } \\
\text { biofilmes em marcapassos }\end{array}$ & $\begin{array}{l}\text { Acta Paulista de } \\
\text { Enfermagem }\end{array}$ & Review & $\begin{array}{l}\text { Identification of the main etiologic } \\
\text { agents responsible by biofilm } \\
\text { formation in pacemakers and its } \\
\text { methods of eradication }\end{array}$ \\
\hline $\begin{array}{l}\text { Stewart P, } \\
\text { Franklin M, } \\
\text { Williamson K, } \\
\text { et al. }\end{array}$ & 2015 & $\begin{array}{l}\text { Contribution of Stress Responses } \\
\text { to Antibiotic Tolerance in } \\
\text { Pseudomonas aeruginosa Biofilms }\end{array}$ & $\begin{array}{l}\text { Antimicrobial } \\
\text { Agents and } \\
\text { Chemotherapy }\end{array}$ & $\begin{array}{l}\text { Observational } \\
\text { study }\end{array}$ & $\begin{array}{l}\text { Ways of modulation against } \\
\text { antimicrobial agents in } \\
\text { Pseudomonas } \\
\text { biofilms }\end{array}$ \\
\hline $\begin{array}{l}\text { Sued B, Pereira } \\
\text { P, Faria Y, et al. }\end{array}$ & 2017 & $\begin{array}{l}\text { Sphygmomanometers and } \\
\text { thermometers as potential fomites } \\
\text { of Staphylococcus haemolyticus: } \\
\text { biofilm formation in the presence } \\
\text { of antibiotics }\end{array}$ & $\begin{array}{c}\text { Memórias do } \\
\text { Instituto Oswaldo } \\
\text { Cruz }\end{array}$ & $\begin{array}{l}\text { Transversal } \\
\text { study }\end{array}$ & $\begin{array}{l}\text { Capacity of biofilm formation into } \\
\text { common hospitalar materials, } \\
\text { especially oxacillin resistance } \\
\text { type, such as Staphylococcus } \\
\text { haemolyticus. }\end{array}$ \\
\hline Tarakji K & 2019 & $\begin{array}{l}\text { Cardiovascular Implantable } \\
\text { Electronic Device Infection }\end{array}$ & $\begin{array}{l}\text { JACC: Clinical } \\
\text { Electrophysiology }\end{array}$ & Review & $\begin{array}{l}\text { Exposed the current management } \\
\text { of biofilm formation in } \\
\text { implantable cardiovascular devices } \\
\text { infections }\end{array}$ \\
\hline $\begin{array}{l}\text { Wang S, Kang } \\
\text { O, Kwon D }\end{array}$ & 2021 & $\begin{array}{l}\text { Trans-Cinnamaldehyde Exhibits } \\
\text { Synergy with Conventional } \\
\text { Antibiotic against Methicillin- } \\
\text { Resistant Staphylococcus aureus }\end{array}$ & $\begin{array}{l}\text { International } \\
\text { Journal of } \\
\text { Molecular } \\
\text { Sciences }\end{array}$ & Experimental & $\begin{array}{l}\text { Ways to improve antimicrobial } \\
\text { resistance in MRSA's biofilms } \\
\text { species }\end{array}$ \\
\hline $\begin{array}{l}\text { Wheeler, } \\
\text { Cárcamo- } \\
\text { Oyarce G, } \\
\text { Turner B et al. }\end{array}$ & 2019 & $\begin{array}{l}\text { Mucin glycans attenuate the } \\
\text { virulence of Pseudomonas } \\
\text { aeruginosa in infection }\end{array}$ & $\begin{array}{c}\text { Nature } \\
\text { Microbiology }\end{array}$ & Experimental & $\begin{array}{l}\text { Mucin glycans may be used as a } \\
\text { prophylactic measure against } \\
\text { biofilm formation, but further } \\
\text { studies are necessary }\end{array}$ \\
\hline $\begin{array}{l}\text { Xu Y, Jones J, } \\
\text { Yu H, et al. }\end{array}$ & 2015 & $\begin{array}{lr}\text { Nanoscale Plasma } & \begin{array}{r}\text { Coating } \\
\text { Formation }\end{array} \\
\text { Inhibits } & \\
\text { of Staphylococcus aureus Biofilm }\end{array}$ & $\begin{array}{l}\text { Antimicrobial } \\
\text { Agents and } \\
\text { Chemotherapy }\end{array}$ & Experimental & $\begin{array}{l}\text { Nanoscale plasma-coated surface } \\
\text { could be an alternative form of } \\
\text { preventing biofilm formation when } \\
\text { compared to current prophylactic } \\
\text { measures }\end{array}$ \\
\hline
\end{tabular}

Source: Authors (2021).

\section{Discussion}

Regarding the biofilm, its growth and composition are heterogeneous, varying according to the strain and environment for proliferation (Marks et al., 2014). Proportionally, 10-20\% of it is made of microorganisms, of which 75-90\% are, on average, EPS (Santos et al., 2011). The main phenotypic difference between biofilms and planktonic cells lies in the susceptibility against antimicrobial agents. The resistance mechanisms developed by colonization strains are more efficient than those by free life parasites (Hall et al., 2017).

For the microbiota to have sustainable growth, biofilms have developed Quorum Sensing (QS), which allows for the bacteria to communicate with one another via gene regulation based on the population density of the microbiota (Brackman et al., 2014; Santos et al., 2011) and a to control the phenotype for the existing colony by restraining the expression of specific genes, such as sporulation and nitrogen capture, permitting the biofilm to increase its capacity to adapt to a new environment (Brackman et al., 2014; Henriques et al., 2013; Hentzer et al., 2003).

Biofilm adhesion is established in two steps. Firstly, there is an unspecific physical-chemical interaction. This means it occurs randomly due to electrostatic forces, such as Van der Waals, covalent and hydrophobic. However, during this phase, there is no molecular interaction, meaning that the adhesion is reversible; to prevent the adhesion, it is possible to use sterilization methods, prophylactic antimicrobials, and immune defense (Araújo et al., 2010; Moraes et al., 2013; Rabin et al., 2015; Nascimento et al., 2018). 
In the second step, the secondary adhesion, there are molecular interactions between the microorganisms and the biomaterial's surface, making this connection irreversible (Rabin et al., 2015; Nascimento et al., 2018). After the initial adhesion, the bacteria start to proliferate and aggregate, forming a matrix with active plasmid transfer, resulting in a higher tolerance to changes in temperature, humidity, $\mathrm{pH}$, as well as the production of toxins and metabolites (Moraes et al., 2013; Nascimento et al., 2018).

As a premise, the biofilm becomes mature - surrounded by its environment and strains, becoming a bacterial arsenal. After the complete biofilm formation, planktonic bacteria detach from it and start to colonize other areas (Henriques et al., 2013; Moraes et al., 2013); it may act as an adaptation to changes in the quantity of substrate available, or even in shearing forces that alter the flow and increase the biofilm's erosion capacity. This mechanism serves as an explanation to why the cell detachment in medical devices happens, which allows them to migrate to the bloodstream and affect different tissues, such as the endocardium in the case of pacemakers (Araújo et al., 2010; Dengler Haunreiter et al., 2019; Rabin et al., 2015).

The highly antimicrobial resistance of biofilms causes persistent infections with chronic characteristics despite antibiotic therapy (Hall et al., 2017). The mechanisms are multifactorial and vary according to the microbial agent, strain, and the cellular community and its stage of development (Hall et al., 2017; Stewart et al., 2015). Overall, the infections are treated by the removal or substitution of the infected medical devices associated with systemic antibiotic therapy (Hall et al., 2017; Ma et al., 2012).

As demonstrated by Al-Shamiri et al., in a study with samples of A. baumanni, one of the main agents of nosocomial infections, the strains were isolated and presented antimicrobial resistance, especially due to the biofilm itself, the matrix, and horizontal gene transfer. The colonization occurred in strains that presented the OXA-type gene. Therefore, the colonization strategy is effective and contributes to the perpetuation of the species in inadequate environments (Al-Shamiri et al., 2021).

Among the antibiotic resistance mechanisms developed by the bacterial community, there are efflux pumps, protease enzyme production - such as beta-lactamase - and proteins that inhibit antimicrobial action; mechanisms associated with a genetic mutation (Hall et al., 2017).

The biofilm's resistance and tolerance to antimicrobials are correlated to its extracellular matrix, an obstacle to drug penetration (Hall et al., 2017). This barrier is formed in the community's basal layer - it has low nutrient access, leading to a slow growth rate, or no growth at all, resulting in transitory tolerance to antibiotics (Dengler Haunreiter et al., 2019). The penetration of these drugs acts at very high concentrations compared to minimal inhibition concentration in normal conditions and depends on the thickness of the biofilm being treated (Al-Shamiri et al., 2021; Hall et al., 2017). Antibiotic prophylaxis significantly reduces the incidence of infectious complications, requiring another operation after permanent pacemaker implantation(Hall et al., 2017; Sousa et al., 2017).

In an Italian study based on 1366 patients with pacemakers, of all the isolated infectious agents on the device, around $51.6 \%$ were strains of S. epidermidis, followed by S. aureus $(6.4 \%)$. Considering that over half of these strains of both microbial agents were oxacillin-resistant, treatment using tetracycline was more efficient in S. aureus strains; fosfomycin was effective against both species (Salmeri et al., 2016; Wang et al., 2021). Despite the therapy with various combinations of different classes of antibiotics resulting in positive outcomes, its extended and diffused use may culminate in the development of a bacterial strain with an even higher antibiotic resistance (Ma et al., 2012; Sousa et al., 2017; Tarakji, 2019; Xu et al., 2015).

In a case report written by Berkefeld et al., a 75-year-old patient presented with cardiac site bacteremia by Clostridium difficile after a pacemaker implantation procedure. The treatment used included vancomycin for 7 days followed by a new surgery to relocate the device. The pathogen tends to be more commonly associated with abdominal infections and 
there haven't been cases reporting $C$. difficile infections in the heart. Usually, these infections are associated with a previous gastrointestinal pathogeny, which was not the case of the patient (Berkefeld et al., 2020).

The number of device-associated infections has increased proportionally to the need for cardiac device use, despite the existence of newer technologies that facilitate the implantation process (Devine, 2014; Sousa et al., 2017).

Besides the chance of contamination by the nosocomial pathway during surgery or post-operatory, there's also direct bacterial dissemination through the skin during the initial cardiac device implantation (Berkefeld et al., 2020). The most common microorganisms isolated in the infected pacemakers are coagulase-negative Staphylococcus, such as S. epidermidis, and coagulase-positive Staphylococcus, S. aureus. Hence, the contamination mechanisms of higher incidence are through skin lesions (Bruna et al., 2019; Ma et al., 2012; Salmeri et al., 2016).

S. epidermidis and S. aureus are the most common etiological agents in biofilm infection, due to their high colonization capacity in catheters and pacemakers (Ma et al., 2012). When contamination develops, the best alternative to eradicate the infection in situations in which antibiotic therapy is not enough is to remove the electrode completely (Bruna et al., 2019; Salmeri et al., 2016). Most complications from an infected device already implanted arise 3 months after the procedure and, without proper medical care, it will evolve to worse clinical stages, such as Infectious Endocarditis (Dengler Haunreiter et al., 2019; Hannachi et al., 2019; Holland et al., 2016; Santos et al., 2011).

Infectious endocarditis (IE) is rare, though it tends to be common among the elderly, patients with implantable cardiac devices, cardiac valve prosthesis, congenic cardiac disease, dialysis patients, and injectable drug users (DeSimone et al., 2020). With the increase of intravenous opioid use, the number of younger patients with IE has increased significantly (DeSimone et al., 2020). The main etiological agents are S. aureus, followed by S. epidermidis (Dengler Haunreiter et al., 2019; DeSimone et al., 2020; Holland et al., 2016). Despite its rareness, it is a potentially fatal disease.

In a systematic review regarding the global incidence of IE, the brute incidence varied from 1.5 to 11.6 cases per 100.000 people-year, with high-quality data available in only 10 developed countries. Even with the best therapy available, the contemporary mortality rate of IE is approximately $25 \%$. The current numbers tend to increase due to cardiac rheumatic diseases, especially in young adults, and degenerative valve disease in geriatric patients. The risk factors for the development of IE are any congenic cardiac disease, cardiac prosthesis implants, such as pacemakers, and intravenous drug use (Holland et al., 2016).

IE, mainly by S. epidermidis, has nosocomial origins, infecting prosthesis, pacemakers, and orthopedic cardiac valves. Septic problems in the implantation environment can trigger a bacterial infection, which, with a resistant strain, develops a bacterial population that is more tolerant to antimicrobials - the longer it takes to treat the patient. The bacterial growth parameters are determined by the environment and intrinsic strain properties (Dengler Haunreiter et al., 2019).

Once established, IE may present in a different site in the organism. Pathological diagnosis is difficult and though rare, has long-term complications, being the most significant contagious factor in hospitals. To achieve the most adequate treatment, it is necessary a multidisciplinary team, with microbiological, echocardiographic, and clinical requisites (Holland et al., 2016). IE is caused by endocardium damages, followed by microbial colonization, usually bacteria. If these colonies are resistant, with low metabolisms, such as biofilms, the complications may be systemic and fatal (Dengler Haunreiter et al., 2019; Holland et al., 2016). The mitral valve prolapse is one of the most common situations for IE development (Holland et al., 2016). The contamination by S. aureus is more related to invasive actions - surgeries, intravenous drugs, and direct contact (Hannachi et al., 2019).

In normal conditions, the valvar endothelium is bacteria-resistant, then, for an infection to install, it is necessary to a series of events to transpire, such as cardiac valve surface changes - promoting a better fixation site for the biofilm bacteremia with organisms capable of fixation and colonization, biofilm maturation with all its structures and virulence. The 
virulence mechanisms of $S$. aureus concoct to a specific surface protein-mediated adhesion, which attach themselves to the fibrinogen as an agglomeration factor and coagulase (Holland et al., 2016).

S. aureus is also capable of attaching to platelets via the Von Willebrand factor, this being one of the key components to its pathogenesis. Despite this, platelets have an immunological role against the mass proliferation of these pathogens and, depending on the virulence, the bacteria will either die or survive; however, basal microorganisms, with reduced metabolism, are more difficult to eradicate, including natural ways and antimicrobials (Hannachi et al., 2019; Holland et al., 2016). Thus, the role of platelets in this scenario is contradictory, acting with the S. aureus through proteins of the complement (Hannachi et al., 2019).

The humoral and cellular responses are active in IE, presenting with splenomegaly and macrophages in peripheral blood. Opsonin, along with the complement, is produced as an immunological attack and an attempt at control-measure against infection in progress; there is a left shift in the myeloid cell lineage(Holland et al., 2016).

Because it is a systemic disease, IE has multiple organ targets. The biofilm matrix, formed by platelet aggregation, fibrin and other substrates, may be liberated to the vascular system and provoke oxygen privation, culminating in infarction of adjacent tissues (Hannachi et al., 2019; Holland et al., 2016). Also, bacteria in their free-life form can infect other tissues, creating abscesses. In the cardiovascular system, the biofilm fauna has potential to compromise the mitral and semilunar valves. The infection can lead to the perforation of the valvar leaflet and rupture of chordae tendineae, with embolic complications. An abscess in the valvar ring and myocardial fistula formation may occur, especially if the agent strain is made of $S$. aureus. The symptoms can be reflected in the kidneys, nervous system, and spleen, which could all suffer from infarction here, due to embolic sepsis (Holland et al., 2016).

The increase of hospitalization indexes increases the risk of contamination. So, patients with implantable cardiac devices, as well as those with risk factors for IE, need to be monitored and checked by doctors regularly. The treatment varies according to the case and established protocol(Holland et al., 2016).

The best option until now is prophylaxis, such as room preparation for special procedures, double sterile gloves, annual inspections and hygiene, and disinfection of material surfaces with Glucoprotamin 0.5\%. Besides the use of PVPI for preoperative skin antisepsis, its use in the short term is controversial and may not be effective (Berkefeld et al., 2020; Tchouaket Nguemeleu et al., 2020).

Therefore, one of the alternatives under study for the elimination of chronic infections caused by biofilm are QS inhibiting agents, and the interference of this phenomenon - effective in the formation and maturation of biofilms - is crucial for the involution of the bacterial community, in addition to antimicrobials (Brackman et al., 2014; Hall et al., 2017). The use of QS inhibitors allows greater adherence to medications, such as vancomycin and cephalosporins, reducing biofilm resistance and tolerance to drug treatments (Brackman et al., 2014; Hall et al., 2017; Hentzer et al., 2003). Despite the exacerbated cytotoxicity and the mutable action against different bacterial strains and cultures, QS inhibitors are a sustainable alternative for biofilm eradication(Brackman et al., 2014).

Currently, still in study, envelopes after surgical procedures for cardiac device implantation have been used as a form of prophylaxis - in addition to the ones already in use - to eventual biofilm infections (Tarakji, 2019). The AIGIS (RX)® is made of an antibiotic mesh, which combines rifampicin with minocycline, and has been efficient in preventing cardiac device colonization and consequential patient clinical infection by S. aureus (Sousa et al., 2017; Tarakji, 2019).

The alteration of biomaterial surfaces is a future possibility to control infections associated with pacemakers, avoiding it due to the device's engineering, aiming to hinder bacterial fixation and multiplication (Sousa et al., 2017; Xu et al., 2015). As an example, there is trimethyl-silane (TMS), used as a monomer to revest devices with stainless steel and titanium alloy surfaces, which are the components used to build devices used in surgical implants (Ma et al., 2012). The study showed that the 
devices coated with TMS inhibited the biofilm's development in vitro, mainly by the pathogen S. epidermidis and, besides, made the bacterial community more susceptible to antibiotic therapy; for this reason, the TMS coating may result in a surface more resistant to the surge of biofilm(Ma et al., 2012; Sousa et al., 2017).

In a publication by Nature Microbiology in 2019, it was revealed that glycosidic mucin, when applied to a surface, reduces the development of biofilm made of Pseudomonas aeruginosa, one of the most common and virulent pathogens. The substance prevents QS communication, one of the most important aspects in the management of the bacterial community population, reducing resistance and tolerance mechanisms of the biofilm to the antimicrobial agents (Wheeler et al., 2019).

\section{Conclusion}

Biofilm, given its pathogenicity and virulence, is a rare and serious complication in patients with implantable cardiac devices. Despite its rareness, there is evidence that this contamination may happen, especially through surgical implantation methods, and that the prognosis is reserved, being it necessary to remove the entire device.

Besides, among the cases of implantable cardiac devices contamination, it is common the development of IE, which affects the cardiovascular tissue, and has a high dissemination capability due to the biofilm's maturation and the detachment of planktonic bacteria. Therefore, patients that use cardiac prosthesis have a notorious presence in the risk factors for IE.

There aren't, now, enough clinical studies to prevent the adhesion of biofilm in such devices. The already existing, such as glycosidic mucin, still need a long period of trials and clinical essays before being used in daily medical practice. Thus, so far, the most effective practice is prevention, with the use of prophylactic antibiotics, coherent sterilization methods, and the use of PPIs by the entire surgical sphere and the patient himself.

Based on the information provided, the authors recommend further studies in the field, focusing on update therapies for this condition, as well as on prophylactic measures against its formation.

\section{References}

Al-Shamiri, M. M., Zhang, S., Mi, P., Liu, Y., Xun, M., Yang, E., Ai, L., Han, L., \& Chen, Y. (2021). Phenotypic and genotypic characteristics of Acinetobacter baumannii enrolled in the relationship among antibiotic resistance, biofilm formation and motility. Microbial Pathogenesis, 155, 104922. https://doi.org/10.1016/j.micpath.2021.104922

Araújo, E. A., Andrade, N. J. de, Carvalho, A. F. de, Ramos, A. M., Silva, C. A. de S., \& Silva, L. H. M. da. (2010). Aspectos coloidais da adesão de microorganismos. Química Nova, 33(9), 1940-1948. https://doi.org/10.1590/S0100-40422010000900022

Berkefeld, A., Berger, F. K., Gärtner, B. C., Wantia, N., Prinzing, A., Laugwitz, K.-L., Busch, D. H., \& Rothe, K. (2020). Clostridioides (Clostridium) difficile Pacemaker Infection. Open Forum Infectious Diseases, 7(12). https://doi.org/10.1093/ofid/ofaa487

Brackman, G., \& Coenye, T. (2014). Quorum Sensing Inhibitors as Anti-Biofilm Agents. Current Pharmaceutical Design, 21(1), 5-11. https://doi.org/10.2174/1381612820666140905114627

Bruna, C. Q. de M., Almeida, A. G. C. dos S., \& Graziano, K. U. (2019). Avaliação da contaminação microbiana em fitas e resinas identificadoras de instrumental cirúrgico. Revista SOBECC, 24(1), 16. https://doi.org/10.5327/10.5327/Z1414-4425201900010004

Haunreiter, D. V., Boumasmoud, M., Häffner, N., Wipfli, D., Leimer, N., Rachmühl, C., Kühnert, D., Achermann, Y., Zbinden, R., Benussi, S., Vulin, C., \& Zinkernagel, A. S. (2019). In-host evolution of Staphylococcus epidermidis in a pacemaker-associated endocarditis resulting in increased antibiotic tolerance. Nature Communications, 10(1), 1149. https://doi.org/10.1038/s41467-019-09053-9

DeSimone, D. C., \& DeSimone, C. (2020). Editorial commentary: Intravenous drug abuse and infectious endocarditis. Trends in Cardiovascular Medicine, 30(8), 498-499. https://doi.org/10.1016/j.tcm.2019.12.001

Devine, A. (2014). Hardware for the Heart: The Increasing Impact of Pacemakers, ICDs, and LVADs. MD Edge Emergency Medicine, 46(2), 56-75.

Hall, C. W., \& Mah, T.-F. (2017). Molecular mechanisms of biofilm-based antibiotic resistance and tolerance in pathogenic bacteria. FEMS Microbiology Reviews, 41(3), 276-301. https://doi.org/10.1093/femsre/fux010

Hannachi, N., Habib, G., \& Camoin-Jau, L. (2019). Aspirin Effect on Staphylococcus aureus—Platelet Interactions During Infectious Endocarditis. Frontiers in Medicine, 6. https://doi.org/10.3389/fmed.2019.00217 
Henriques, A. F. F. M., Vasconcelos, C., \& Cerca, N. (2013). A importância dos biofilmes nas infecções nosocomiais: o estado da arte. Arquivos de Medicina, $27-36$.

Hentzer, M., \& Givskov, M. (2003). Pharmacological inhibition of quorum sensing for the treatment of chronic bacterial infections. Journal of Clinical Investigation, 112(9), 1300-1307. https://doi.org/10.1172/JCI20074

Holland, T. L., Baddour, L. M., Bayer, A. S., Hoen, B., Miro, J. M., \& Fowler, V. G. (2016). Infective endocarditis. Nature Reviews Disease Primers, 2(1), 16059. https://doi.org/10.1038/nrdp.2016.59

Ma, Y., Chen, M., Jones, J. E., Ritts, A. C., Yu, Q., \& Sun, H. (2012). Inhibition of Staphylococcus epidermidis Biofilm by Trimethylsilane Plasma Coating. Antimicrobial Agents and Chemotherapy, 56(11), 5923-5937. https://doi.org/10.1128/AAC.01739-12

Marks, L. R., Reddinger, R. M., \& Hakansson, A. P. (2014). Biofilm Formation Enhances Fomite Survival of Streptococcus pneumoniae and Streptococcus pyogenes. Infection and Immunity, 82(3), 1141-1146. https://doi.org/10.1128/IAI.01310-13

Moraes, M. N. Silveira, W. C. D., Teixeira, L. L. E. M., \& Araújo, I. D. (2013). Mechanisms of bacterial adhesion to biomaterials. Revista Médica de Minas Gerais, 23(1), 99-104.

Nascimento, I. R., Lima de Sena, T., Fernandes dos Santos Castro, F., Pereira Correia de Souza, P., \& Nomiyama Figueiredo, F. (2018). Biofilmes bacterianos: colonização e identificação de micro-organismos causadores de infecção em cateter venoso central. Programa de Iniciação Científica PIC/UniCEUB - Relatórios de Pesquisa, 2. https://doi.org/10.5102/pic.n2.2016.5586

Nguemeleu, E. T., Boivin, S., Robins, S., Sia, D., Kilpatrick, K., Brousseau, S., Dubreuil, B., Larouche, C., \& Parisien, N. (2020). Development and validation of a time and motion guide to assess the costs of prevention and control interventions for nosocomial infections: A Delphi method among experts. PLOS ONE, 15(11), e0242212. https://doi.org/10.1371/journal.pone.0242212

Rabin, N., Zheng, Y., Opoku-Temeng, C., Du, Y., Bonsu, E., \& Sintim, H. O. (2015). Biofilm formation mechanisms and targets for developing antibiofilm agents. Future Medicinal Chemistry, 7(4), 493-512. https://doi.org/10.4155/fmc.15.6

Salmeri, M., Sorbello, M. G., Mastrojeni, S., Santanocita, A., Milazzo, M., di Stefano, G., Scalia, M., Addamo, A., Toscano, M. A., Stefani, S., \& Mezzatesta, M. L. (2016). Infections of cardiovascular implantable electronic devices: 14 years of experience in an Italian hospital. Le Infezioni in Medicina, 2, $131-136$.

Santos, A. P. A., Watanabe, E., \& Andrade, D. de. (2011). Biofilme em marca-passo artificial: ficção ou realidade? Arquivos Brasileiros de Cardiologia, 97(5), e113-e120. https://doi.org/10.1590/S0066-782X2011001400018

Sousa, Á. F. L. de, Marques, D. M., Monteiro, R. M., Queiroz, A. A. F. L., Andrade, D., \& Watanabe, E. (2017). Prevenção da formação de biofilmes em marcapassos artificiais: é viável? Acta Paulista de Enfermagem, 30(6), 644-650. https://doi.org/10.1590/1982-0194201700085

Stewart, P. S., Franklin, M. J., Williamson, K. S., Folsom, J. P., Boegli, L., \& James, G. A. (2015). Contribution of Stress Responses to Antibiotic Tolerance in Pseudomonas aeruginosa Biofilms. Antimicrobial Agents and Chemotherapy, 59(7), 3838-3847. https://doi.org/10.1128/AAC.00433-15

Sued, B. P. R., Pereira, P. M. A., Faria, Y. V., Ramos, J. N., Binatti, V. B., Santos, K. R. N. dos, Seabra, S. H., Hirata Júnior, R., Vieira, V. V., MattosGuaraldi, A. L., \& Pereira, J. A. A. (2017). Sphygmomanometers and thermometers as potential fomites of Staphylococcus haemolyticus: biofilm formation in the presence of antibiotics. Memórias Do Instituto Oswaldo Cruz, 112(3), 188-195. https://doi.org/10.1590/0074-02760160381

Tarakji, K. G. (2019). Cardiovascular Implantable Electronic Device Infection. JACC: Clinical Electrophysiology, 5(9), 1081-1083. https://doi.org/10.1016/j.jacep.2019.05.026

Wang, S., Kang, O.-H., \& Kwon, D.-Y. (2021). Trans-Cinnamaldehyde Exhibits Synergy with Conventional Antibiotics against Methicillin-Resistant Staphylococcus aureus. International Journal of Molecular Sciences, 22(5), 2752. https://doi.org/10.3390/ijms22052752

Wheeler, K. M., Cárcamo-Oyarce, G., Turner, B. S., Dellos-Nolan, S., Co, J. Y., Lehoux, S., Cummings, R. D., Wozniak, D. J., \& Ribbeck, K. (2019). Mucin glycans attenuate the virulence of Pseudomonas aeruginosa in infection. Nature Microbiology, 4(12), 2146-2154. https://doi.org/10.1038/s41564-019-0581-8

Xu, Y., Jones, J. E., Yu, H., Yu, Q., Christensen, G. D., Chen, M., \& Sun, H. (2015). Nanoscale Plasma Coating Inhibits Formation of Staphylococcus aureus Biofilm. Antimicrobial Agents and Chemotherapy, 59(12), 7308-7315. https://doi.org/10.1128/AAC.01944-15 